\title{
Nieobronne obiekty przyforteczne zewnętrznego pierścienia umocnień Twierdzy Toruń na początku lat dwudziestych XX wieku
}

\author{
Pawet Nastrożny
} Gdańsk, Toruń

Zachowane w granicach dzisiejszej Polski dawne zespoły obronne mają znaczną wartość historyczną. Oprócz różnych działań podejmowanych $w$ celu utrzymania ich $w$ jak najlepszym stanie ważnym elementem jest prowadzenie badań naukowych. Dotyczy to również dawnej Twierdzy Toruń, a w sposób szczególny fortyfikacji powstałych w XIX i na początku XX stulecia. Dzieje tej warowni są poznane tylko w części, mimo wielu cennych inicjatyw podejmowanych w celu wypełnienia istniejących luk w historiografii ${ }^{1}$.

Przedmiotem niniejszego szkicu jest sumaryczne zaprezentowanie obiektów nieobronnych znajdujących się w obrębie zewnętrznego pierścienia fortecznego twierdzy toruńskiej na początku lat dwudziestych XX w., a w sposób szczególny w stanie z roku 1920, a więc

\footnotetext{
${ }^{1}$ Najważniejszą z nich wydaje się być seria „Atlas Twierdzy Torun”, istniejąca na rynku wydawniczym od 2005 r. Do początku 2016 r. ukazało się 8 zeszytów: Historia i źródła fortyfikacji Twierdzy Toruń, red. M. Biskup i L. Narębski, Toruń 2005; Fort Kolejowy (Eisenbahnfort), red. M. Biskup i L. Narębski, Torun 2006; Fort Jakuba (Jacobsfort), red. M. Biskup i L. Narębski, Torun 2007; K. Kawa, Fort I - Jan III Sobieski (Buchtafort; Fort Ia - Feste König Wilhelm I), red. M. Biskup i L. Narębski, Toruń 2008; J. Pokrzywnicki, Fort II - Stefan Czarniecki (Fort I - Bülow), red. J. Tandecki i L. Narębski, Toruń 2010; tenże, Bramy Twierdzy Toruń, red. J. Tandecki i L. Narębski, Toruń 2013; L. Narębski, M. Wichrowski, Fort IX - Bolestaw Chrobry (Fort IVa - Heinrich von Plauen), red. J. Tandecki i L. Narębski, Toruń 2014; M. Wichrowski, L. Narębski, Fort IV - Żótkiewski (Fort - Yorck), red. J. Tandecki i L. Narębski, Toruń 2015.
} 
w czasie następującym bezpośrednio po przejęciu miasta i fortyfikacji $\mathrm{z}$ rąk niemieckich. Tytułowe budowle nie miały bezpośredniego znaczenia militarnego. Nie były to umocnienia, lecz infrastruktura zaplecza pełniąca funkcje mieszkalne (domy wałmistrzów i robotników), gospodarcze (np. stajnie, pralnie) czy też magazynowe (np. szopy do składowania materiału). W większości obiekty te były zlokalizowane na gruntach fortecznych, w pobliżu samych dzieł fortyfikacyjnych - w rejonie ich działek, zawsze na zapolu. Większość wybudowano w latach osiemdziesiątych i dziewięćdziesiątych XIX stulecia. W legendach niektórych planów ukazujących ich położenie określane są one najczęściej jako „budynki stare”, w odróżnieniu od obiektów „nowych”, wzniesionych na ogół już w dwudziestoleciu międzywojennym.

Architektura nieobronna, choć odgrywała istotne role w sprawnym funkcjonowaniu samych umocnień, na ogół nie spotyka się z zainteresowaniem badaczy dziejów fortyfikacji. W tej grupie pewien wyjątek stanowią jedynie domy wałmistrzów. Dlatego celowe wydaje się zwrócenie uwagi czytelników na wszystkie te obiekty, choćby przez zarysowanie problemu i dalszych potrzeb badawczych, co jest również celem tego szkicu.

Artykuł powstał w oparciu przede wszystkim o materiały źródłowe zgromadzone w zasobach Centralnego Archiwum Wojskowego w Warszawie-Rembertowie ${ }^{2}$ oraz Archiwum Państwowego w Toruniu.

Oprócz podstawowych informacji dotyczących poszczególnych budowli (położenie, funkcja, wymiary) w tekście będzie przedstawiona ich krótka charakterystyka, z naciskiem położonym na ogólną konstrukcję budowlaną. Obiekty zostaną ukazane z podziałem na dwie grupy, znajdujące się na prawym i lewym brzegu Wisły. Przy prezentacji zagadnień przyjęto porządek zgodny z numeracją fortów toruńskich właściwą dla okresu międzywojennego, z uwzględnieniem dzieł obronnych niebędących $\mathrm{w}$ rzeczywistości typowymi fortami ${ }^{3}$. Wymieniane forty-

\footnotetext{
${ }^{2}$ Od czerwca 2016 r. Archiwum jest komórką wewnętrzną Wojskowego Biura Historycznego powstałego z połączenia Centralnego Archiwum Wojskowego oraz Wojskowego Biura Badań Historycznych Wojskowego Centrum Edukacji Obywatelskiej.

3 Por. W. Rezmer, Garnizon Torunia w latach 1920-1939, [w:] Historia Torunia, t. III, cz. II: W czasach Polski Odrodzonej i okupacji niemieckiej (1920-1945), red. M. Biskup, Torun 2006, s. 252.
} 
fikacje nie są charakteryzowane, gdyż każdy zainteresowany z łatwością odnajdzie podstawowe, jak i bardziej szczegółowe informacje na ich temat w publikacjach naukowych bądź w licznie reprezentowanej na rynku grupie pozycji popularnonaukowych.

Należy jeszcze raz zaznaczyć, że przedmiotem tego szkicu są jedynie obiekty nieobronne w ramach zewnętrznego pierścienia obronnego Twierdzy Torun ${ }^{4}$. Został on wyznaczony przez budowę linii fortów w znacznym odsunięciu od centrum całego założenia fortecznego. W międzypolach fortów wzniesiono dodatkowe dzieła warowne, jak choćby dwie baterie pancerne haubic kal. $15 \mathrm{~cm}$, baterię doświadczalną armaty kal. $10 \mathrm{~cm}(105 \mathrm{~mm})$, baterię półpancerną armat kal. $10 \mathrm{~cm}(105 \mathrm{~mm})$. Zewnętrzną linię obronną wzmocniono także budową schronów przeznaczonych dla piechoty, artylerzystów (obsług dział polowych) i amunicji.

\section{Obiekty nieobronne w prawobrzeżnej części zewnętrznego pierścienia fortecznego}

Na wschodnim skraju prawobrzeżnej części twierdzy toruńskiej znajdował się Fort I „Warownia Jana III Sobieskiego”. Po lewej stronie bezpośredniej drogi dojazdowej (sięgacza) do tego kompleksu, w pobliżu samego fortu ${ }^{5}$ istniało osiem różnego rodzaju obiektów zaplecza. W tej grupie podstawą był służbowy dom mieszkalny wałmistrza $^{6}$. Wzniesiono go w konstrukcji muru pruskiego (niem. Fachwerk) ${ }^{7}$.

\footnotetext{
${ }^{4}$ Budowle nieobronne towarzyszące bezpośrednio fortyfikacjom istniały również w rdzeniu twierdzy toruńskiej, tzw. pierścieniu wewnętrznym, po obu stronach Wisły.

${ }^{5}$ Wojskowe Biuro Historyczne, Centralne Archiwum Wojskowe (dalej cyt. CAW), sygn. I.371.8.495, Plan gruntów przy warowni Jana III Sobieskiego w Toruniu, 10 VI $1926 \mathrm{r}$.

${ }^{6}$ Wałmistrz (niem. Wallmeister) był to najczęściej specjalnie przeszkolony podoficer lub cywilny pracownik wojska. Do jego obowiązków należało dbanie o ochronę fortyfikacji w okresie pokoju oraz ich należytą konserwację. Funkcję tę zachowano w polskich urzędach administrujących umocnieniami w okresie dwudziestolecia międzywojennego. Wałmistrz podlegał wówczas oficerom odcinkowym twierdz i sprawował nadzór nad niższym personelem fortecznym (m.in. dozorcami wałowymi).

${ }^{7}$ Mur pruski - potocznie stosowana nazwa określająca konstrukcję ryglową w odniesieniu do obiektów, których wypełnienie pól międzyryglowych stanowi cegła cera-
} 
Miał wymiary 12,6 x 10,2 m i wysokość 4,5-5,0 m. Dom był jednopiętrowy, z dachem dwuspadowym krytym papą. Na parterze znajdowały się pięć ogrzewanych pomieszczeń oraz kuchnia z piecem kuchennym $^{8}$. Piwnica użytkowa miała drewniany strop. W bliskiej odległości od domu znajdował się zewnętrzny ustęp (o wymiarach 3,0 x 1,5 m i wysokości 2,0-2,5 m) z dołem kloacznym ${ }^{9}$.

W odniesieniu do wszystkich wymienianych w tym opracowaniu służbowych domów wałmistrzów należy zaznaczyć, że zazwyczaj jedno $\mathrm{z}$ ich pomieszczeń w kondygnacji parterowej (przyziemnej) było użytkowane jako biuro. Pozostałe pokoje stanowiły część mieszkalną dla wałmistrza i jego rodziny oraz ewentualnie także dla niewielkiej służby.

Oprócz domu mieszkalnego w użytkowaniu wałmistrza były też obiekty zaplecza gospodarczego, takie jak stajnie, stodoły, magazyny itp. Na zapleczu „Warowni Sobieskiego” pierwszym z nich była obszerna, dwukondygnacyjna szopa wzniesiona w konstrukcji drewnianej, zajmująca powierzchnię całkowitą $186 \mathrm{~m}^{2}$, w której zgodnie z pierwotnym przeznaczeniem miały być składowane materiały budowlane, np. cement. Pokrycie dwuspadowego dachu stanowiła papa. Wewnątrz znajdowały się cztery wydzielone pomieszczenia.

Kolejne obiekty to stodoła i dwie stajnie. Stodoła była niewielka, o wymiarach 5,0 x 2,6 m i wysokości 2,5-3,0 m. Stajnie były większe; pierwsza $\mathrm{z}$ nich, zajmująca powierzchnię łączną $32,76 \mathrm{~m}^{2}$, została

miczna. M. Witek, C. Nowakowski, Między stupem i ryglem. Swojskie dziedzictwo Pomorza Zachodniego, Szczecin 2012, s. 117. Por. także przypis 10.

${ }^{8}$ Często były to tzw. ,angielki”. Por. CAW, sygn. I.371.8.451, Wykaz robót konserwacyjnych w obiektach fortecznych z Dz. Budż. Int. dz. 1 - rozdz. $1-\S 5$.

${ }^{9}$ Archiwum Państwowe w Toruniu (dalej cyt. APT), sygn. 183/18, Protokół zdawczo-odbiorczy ruchomości i nieruchomości wojskowych przejętych w styczniu i lutym 1920 roku na podstawie traktatu pokojowego przez D.O.G. Pomorze od Rządu niemieckiego, zał. I/1, Rozprawa oddawcza fortyfikacji w Toruniu w sprawie oddania dzieł fortecznych, gruntów i budynków rządowi polskiemu, Toruń, 13 I 1920 r.; zał. $\mathrm{I} / 3$, Opis dzieł fortecznych, gruntów i budynków oddanych rządowi polskiemu przez fortyfikację, Toruń, 13 I 1920 r.; CAW, Plany fortyfikacji Chełmno, Grudziądz, Toruń, sygn. I.371.8.453, Wykaz budowli nieobronnych twierdzy Toruń, Dowództwo Obozu Warownego „Toruń” (dalej cyt. DOW „Toruń) - Zarząd Fortyfikacyjny, zał. do pisma L.dz. 1168/F z dn. 21 VII 1920 r. 
wzniesiona w konstrukcji ryglowej ${ }^{10}$, oszalowanej deskami. Drugi budynek stajni był nieco większy $\left(37,7 \mathrm{~m}^{2}\right)$, murowany z cegły, z dwuspadowym dachem krytym dachówką.

W kompleksie obiektów zaplecza Fortu I znajdowały się również dwa domy mieszkalne robotników, którzy pozostawali na stałym etacie wojska w okresie zaboru i zajmowali się utrzymaniem w należytym porządku terenów fortyfikacji, podlegając służbowo wałmistrzowi fortu. Oba budynki wzniesiono z cegły, a dwuspadowy dach kryty był dachówką. W każdym z nich mieściły się po trzy pokoje ogrzewane piecami, kuchnia $\mathrm{z}$ piecem kuchennym, strych oraz piwnica $\mathrm{z}$ drewnianym stropem. Domy zajmowały powierzchnię łączną 105,41 $\mathrm{m}^{2} \mathrm{i} 130,2 \mathrm{~m}^{211}$.

Za kompleksem Fortu I, wraz z towarzyszącymi mu bateriami artylerii zapola i schronami międzypolowymi, następnym ważnym ogniwem pierścienia umocnień był Fort II „Warownia Stefana Czarnieckiego". W okolicach drogi dojazdowej do kompleksu istniało sześć obiektów zaplecza $^{12}$. Podstawę stanowił dom wałmistrza ${ }^{13}$, wzniesiony w konstrukcji zbliżonej do tego rodzaju obiektu przy Forcie I. Różnicą było krycie dachu - w tym przypadku był to łupek ${ }^{14}$. Na parterze znaj-

\footnotetext{
${ }^{10}$ Konstrukcja ryglowa (określana też szachulcową) - technika budowy obiektów architektury, w których szkielet nośny wykonany jest z drewna dębowego lub sosnowego (częściej stosowane od połowy XIX w.), a jego wypełnienie stanowi cegła ceramiczna lub surowa albo glina. M. Witek, C. Nowakowski, op. cit., s. 6-9. W przypadku tego tekstu najczęściej konstrukcja ryglowa oznacza wypełnienie szkieletu gliną, bardzo często $\mathrm{z}$ dodatkowym szalunkiem $\mathrm{z}$ drewna (jedno- lub obustronnym).

${ }^{11}$ APT, sygn. 183/18, zał. I/1, Rozprawa oddawcza fortyfikacji w Toruniu; zał. I/3, Opis dzieł fortecznych, gruntów i budynków oddanych rządowi polskiemu przez fortyfikację; CAW, sygn. I.371.8.453, Wykaz budowli nieobronnych twierdzy Torun.

${ }^{12}$ Plany z lutego 1926 r. pokazują większą ilość obiektów na zapleczu fortu. Część $\mathrm{z}$ nich została zapewne wzniesiona w pierwszej połowie lat dwudziestych XX w. Por. CAW, sygn. I.371.8.487, Plan gruntów z granicznikami przy Warowni Czarnieckiego, 14 II $1926 \mathrm{r}$

${ }^{13}$ Jeszcze w styczniu 1920 r., przed przejęciem obiektu przez polskie wojsko, dom był w części wykorzystywany przez załogę składnicy artyleryjskiej. APT, sygn. 183/18, zał. I/3, Opis dzieł fortecznych, gruntów i budynków oddanych rządowi polskiemu przez fortyfikację.

${ }^{14}$ Łupek - rodzaj pokrycia dachu wykonany z przyciętych w regularny kształ płytek skały osadowej lub metamorficznej. M. Witek, C. Nowakowski, op. cit., s. 117. Łupek wykorzystywany jest w sztuce dekarskiej od ponad dwustu lat. Ten rodzaj pokrycia szczególnie rozpowszechnił się w Niemczech.
} 
dowało się sześć ogrzewanych izb oraz kuchnia, a na poddaszu dwa kolejne pokoje, również ogrzewane. Dom był podpiwniczony (dwa pomieszczenia). Całość miała wymiary 16,3 x 9,3 m i wysokość 5,5$7,5 \mathrm{~m}$. W pobliżu budynku istniał ustęp drewniany z pięcioma oczkami latrynowymi, zajmujący łączną powierzchnię $7,15 \mathrm{~m}^{2}$.

Wśród obiektów zaplecza znajdowała się m.in. szopa na cement. Jej długość wynosiła 20,2 m, a szerokość 9,0 m. Nie różniła się w konstrukcji od podobnego budynku w okolicach Fortu I. Kolejne dwa obiekty to pralnie, wykonane $\mathrm{z}$ drewna, $\mathrm{z}$ dwuspadowym dachem krytym papą. Każda $\mathrm{z}$ nich miała jedno pomieszczenie o wymiarach 4,5 x 3,2 m i wysokości 2,4-3,1 m.

Stajnia przy Forcie II była zbudowana z muru pruskiego z dachem dwuspadowym pokrytym papą. Jej powierzchnię zagospodarowano na cztery pomieszczenia ${ }^{15}$.

Rejon Fortu III „Warowni Stanisława Jabłonowskiego” oraz tzw. „Długiej Baterii” artylerii był pozbawiony obiektów nieobronnych bezpośredniego zaplecza umocnien ${ }^{16}$.

Kolejne tego rodzaju budynki istniały w okolicach Fortu IV „Warowni Żółkiewskiego", po obu stronach drogi dojazdowej ${ }^{17}$. Jak przy większości innych fortów, również tam stał dom mieszkalny wałmistrza. Ten wysoki (7,0-7,8 m) obiekt wzniesiono z cegły. Dach w konstrukcji dwuspadowej kryła dachówka. Na parterze mieściły się trzy ogrzewane pokoje oraz kuchnia z piecem (płytą), na piętrze zaś dodatkowy ogrzewany pokój oraz strych. Dom był podpiwniczony. Budynek miał wymiary 11,3 x 10,9 m. Obok znajdował się drewniany ustęp.

W pobliżu obiektu mieszkalnego wałmistrza zbudowano dwie stajnie o wymiarach 4,4 x 3,9 m i 4,2 x 4,2 m. Pierwsza była murowana $\mathrm{z}$ cegły, miała jednospadowy dach z papą i nie była dzielona. Drugą,

${ }^{15}$ APT, sygn. 183/18, zał. I/1, Rozprawa oddawcza fortyfikacji w Toruniu; zał. I/3, Opis dzieł fortecznych, gruntów i budynków oddanych rządowi polskiemu przez fortyfikację; CAW, sygn. I.371.8.453, Wykaz budowli nieobronnych twierdzy Torun.

16 Por. CAW, sygn. I.371.8.453, Wykaz budowli nieobronnych twierdzy Torun; sygn. I.371.8.484, Plan gruntów przy warowni Jabłonowskiego, 2 IV 1926 r.; sygn. I.371.8.398, Protokół zdawczo-odbiorczy referatu fortyfikacyjnego Kierownictwa Rejonu Inżynierii i Saperów, Toruń, 30 XI 1925 r.

${ }^{17}$ CAW, sygn. I.371.8.497, Warownia Żółkiewskiego. Plan gruntów, 22 IV 1926 r. 
kwadratową, wykonano w konstrukcji muru pruskiego $\mathrm{z}$ dwuspadowym przykryciem z papą i wyodrębniono w niej dwa pomieszczenia ${ }^{18}$.

Duży kompleks składający się z ośmiu nieobronnych obiektów zaplecza istniał przy drodze rokadowej twierdzy w pobliżu Fortu $\mathrm{V}$ „Warowni Jana Karola Chodkiewicza" (ryc. 1). Podstawę stanowił dom mieszkalny wałmistrza fortecznego, znajdujący się tuż przy forcie, po lewej stronie drogi dojazdowej ${ }^{19}$. Miał wymiary 8,0 x 7,6 m i wysokość 3,2-4,3 m, był więc mniejszy w porównaniu $\mathrm{z}$ wcześniej omówionymi. Konstrukcja budynku była drewniana, oszalowana deskami, $\mathrm{z}$ dachem dwuspadowym krytym papą (ryc. 2). Wewnątrz mieściły się dwa ogrzewane pokoje i kuchnia oraz strych na poddaszu. Pod przyziemiem znajdowała się piwnica ze stropem drewnianym. W podobnej konstrukcji wzniesiono ustęp o wymiarach 4,4 x 1,6 m, z trzema oczkami latrynowymi.

W pobliżu domu, po obu stronach drogi dojazdowej, znajdowały się dwie szopy, z pierwotnym przeznaczeniem do magazynowania materiału budowlanego. Obie miały podobne wymiary i powierzchnię około $120 \mathrm{~m}^{2}$. Wzniesiono je $\mathrm{z}$ drewna, $\mathrm{z}$ dachem krytym papa. Kolejnym budynkiem zaplecza była stajnia zbudowana w tej samej konstrukcji i złożona z czterech pomieszczeń. Całość miała wymiary 11,7 x 7,6 m.

$\mathrm{Na}$ zapolu Fortu $\mathrm{V}$ znajdował się również dom mieszkalny robotnika. Był to jednopiętrowy budynek o wymiarach 11,45 x 9,0 m, w konstrukcji ryglowej, oszalowanej od wewnątrz i zewnątrz deskami. Dach pokrywała papa. Były tu cztery pokoje, zapewne ogrzewane, oraz kuchnia i spiżarnia. Nie wiadomo, czy dom był podpiwniczony, obok ulokowano niewielki ustęp $(1,5 \times 1,2 \mathrm{~m}) \mathrm{z}$ muru pruskiego i pralnię $(4,85 \mathrm{x}$ $3,28 \mathrm{~m}$ ), wzniesioną w konstrukcji podobnej do budynku mieszkalnego ${ }^{20}$.

Dokumenty z $1920 \mathrm{r}$. wzmiankują też istniejący fragment ogrodzenia posesji długości $66,0 \mathrm{~m}$, wykonanego ze sztachet drewnianych o wyso-

${ }^{18}$ APT, sygn. 183/18, zał. I/1, Rozprawa oddawcza fortyfikacji w Toruniu; zał. I/3, Opis dzieł fortecznych, gruntów i budynków oddanych rządowi polskiemu przez fortyfikację; CAW, sygn. I.371.8.453, Wykaz budowli nieobronnych twierdzy Toruń.

${ }^{19}$ CAW, sygn. I.371.8.485, Warownia Chodkiewicza. Plan gruntów, 2 V 1926 r.

${ }^{20}$ APT, sygn. 183/18, zał. I/1, Rozprawa oddawcza fortyfikacji w Toruniu; zał. I/3, Opis dzieł fortecznych, gruntów i budynków oddanych rządowi polskiemu przez fortyfikację; CAW, sygn. I.371.8.453, Wykaz budowli nieobronnych twierdzy Torun. 


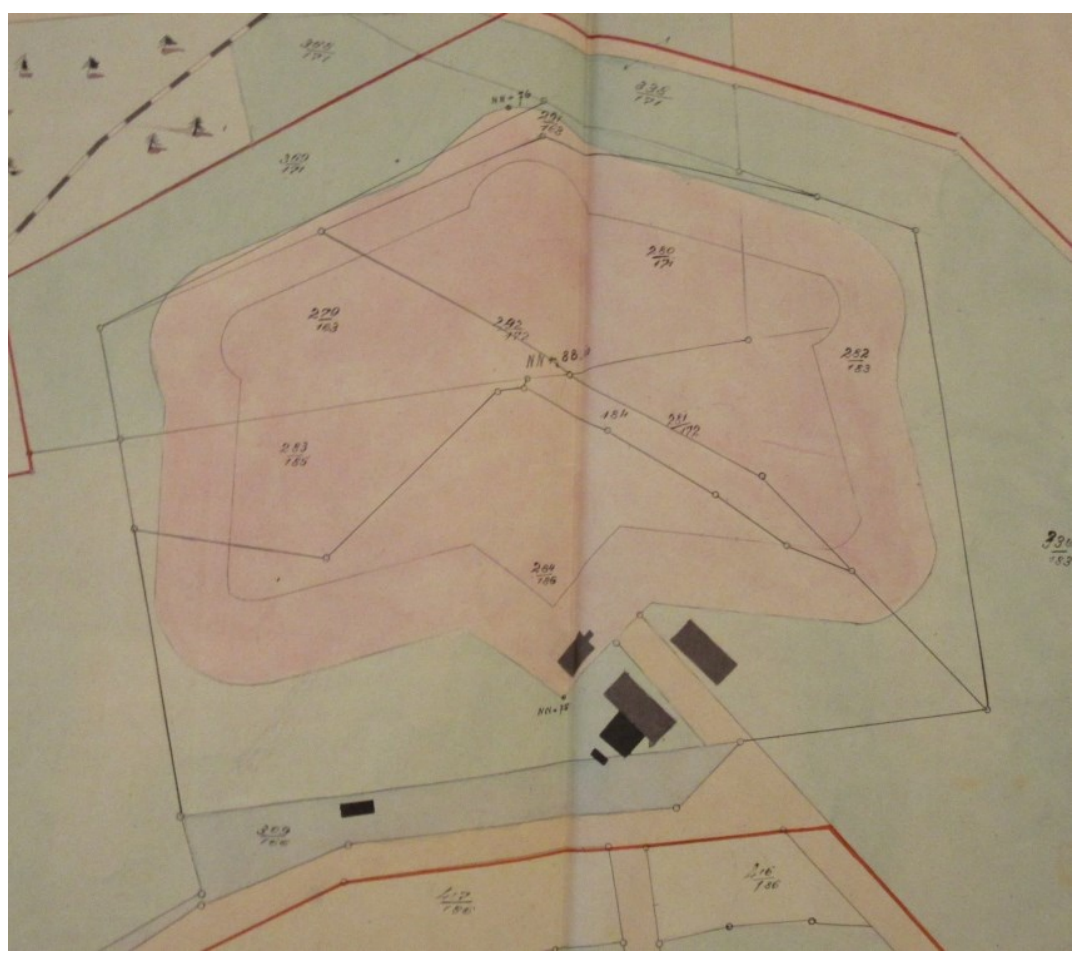

Ryc. 1. Budynki nieobronne przy Forcie V Twierdzy Toruń, stan z początku 1926 r. CAW, sygn. I.371.8.485, Warownia Chodkiewicza.

Plan gruntów, 2 V 1926 r. (fragment)

kości $2,1 \mathrm{~m}^{21}$. Nie jest to pewne, jednak prawdopodobnie płot ten grodził zabudowania domu robotnika wraz $\mathrm{z}$ przyległościami. $\mathrm{Z}$ kolei $\mathrm{w}$ późniejszych materiałach archiwalnych odnotowane są informacje dotyczące łaźni wzniesionej z blachy falistej, która także miała znajdować się na zapolu Fortu $\mathrm{V}^{22}$.

\footnotetext{
${ }^{21}$ Ibid.

${ }^{22}$ CAW, sygn. I.371.8.398, Protokół zdawczo-odbiorczy referatu fortyfikacyjnego Kierownictwa Rejonu Inżynierii i Saperów, Toruń, 30 XI 1925 r.
} 


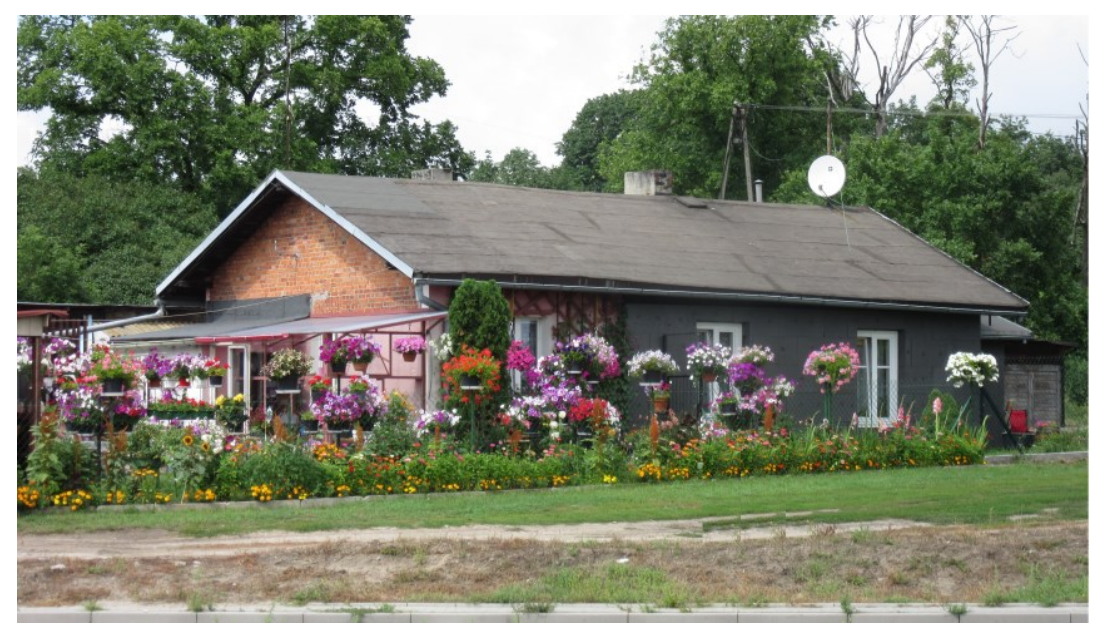

Ryc. 2. Dom wałmistrza przy Forcie V (wtórnie przebudowany), stan z 2016 r. Fot. P. Nastrożny

Pośredni fort piechoty - Fort VI „Warownia Jaremy Wiśniowieckiego" - miał zaplecze rozmieszczone w kilku różnych miejscach. Przy samym forcie zlokalizowany był dom mieszkalny z ustępem, wykonany z muru pruskiego. Obok znajdowały się dwie szopy, w tym jedna mieszcząca też pralnię. $\mathrm{W}$ przypadku tych obiektów nie można podać dokładniejszych informacji ${ }^{23}$.

Kolejnym budynkiem był dom mieszkalny (prawdopodobnie wałmistrza), istniejący po zachodniej stronie szosy na Chełmno, obok skrzyżowania $\mathrm{z}$ drogą rokadową, tuż przy lesie, jeszcze przed rozwidleniem drogi dochodzącej bezpośrednio do fortu ${ }^{24}$. Był murowanym, jednopię-

${ }^{23}$ Ibid

${ }^{24}$ CAW, sygn. I.371.8.398, Protokół zdawczo-odbiorczy referatu fortyfikacyjnego Kierownictwa Rejonu Inżynierii i Saperów, Torun, 30 XI 1925 r.; sygn. I.371.8.496, Warownia Wiśniowieckiego. Plan gruntów, 2 VI 1926 r. Właśnie taką lokalizację - w opozycji do tradycyjnego położenia na bliskim zapolu samego fortu - potwierdza również mapa niemieckiej proweniencji z 1909 r., z zaznaczeniem parcel terenu i budynków użytkowanych przez wałmistrza. Archiwum Map Zachodniej Polski (dalej cyt. AMZP), 
trowym budynkiem o wymiarach 16,0 x 8,0 m, pod dachem dwuspadowym krytym łupkiem. W przyziemiu mieściły się trzy ogrzewane pokoje i kuchnia z płytą. Na poddaszu - pokój, dwie komory i strych. Dom był podpiwniczony. Do obiektu mieszkalnego przylegał ustęp w konstrukcji ryglowej z zewnętrznym szalunkiem z desek (1,2 x 2,2 m).

Stajnię ulokowano niedaleko skrzyżowania drogi rokadowej twierdzy z szosą na Chełmno, po wschodniej stronie tej ostatniej. Budynek miał dwie kondygnacje. Wykonano go z muru pruskiego z dachem krytym papą. Obiekt miał wymiary $5,5 \times 4,5 \mathrm{~m}^{25}$.

Kompleks siedmiu budynków nieobronnych znajdował się na początku lat dwudziestych na zapolu Fortu VII „Warowni Tadeusza Kościuszki”. Taki wniosek można wysnuć na podstawie istniejących planów, na których są one schematycznie zaznaczone ${ }^{26}$. Na temat tych obiektów milczy część źródeł aktowych polsko-niemieckiej i polskiej proweniencji, zarówno dokumenty dotyczące przejęcia fortyfikacji $\mathrm{w}$ styczniu 1920 r., jak i późniejsze wykazy ${ }^{27}$, z wyjątkiem jednego ${ }^{28}$. Budynki są pojedynczo wzmiankowane w dokumentacji dotyczącej administrowania fortyfikacjami ${ }^{29}$. Ze względu na braki w materiałach archiwalnych niemożliwe jest dokładne przedstawienie istniejących tam obiektów w okresie, którego dotyczy niniejszy tekst. Prawdopodobnie

Thorn, 1909, nr 2977, http://amzpbig.com/maps/2977_Thorn_1909.jpg, [dostęp z dn. 28.04.2016 r.].

${ }^{25}$ APT, sygn. 183/18, zał. I/1, Rozprawa oddawcza fortyfikacji w Toruniu; zał. I/3, Opis dzieł fortecznych, gruntów i budynków oddanych rządowi polskiemu przez fortyfikację; CAW, sygn. I.371.8.453, Wykaz budowli nieobronnych twierdzy Toruń.

${ }^{26}$ CAW, sygn. I.371.8.494, Warownia Kościuszki. Plan gruntów, 5 VI 1926 r. Por. AMZP, Thorn, 1909, nr 2977, http://amzpbig.com/maps/2977_Thorn_1909.jpg, [dostęp z dn. 28.04.2016 r.].

${ }^{27}$ Por. APT, sygn. 183/18, zał. I/1, Rozprawa oddawcza fortyfikacji w Toruniu; zał. I/3, Opis dzieł fortecznych, gruntów i budynków oddanych rządowi polskiemu przez fortyfikację; sygn. 183/19, [Regulacja wartości majątku twierdzy przez Komisję Odszkodowań w Paryżu oraz materiały dotyczące polsko-niemieckich rokowań w Dreźnie na temat zwrotu archiwów], Operat szacunkowy gruntów twierdzy Torunia, [1921 r.]; CAW, sygn. I.371.8.453, Wykaz budowli nieobronnych twierdzy Torun.

${ }^{28}$ CAW, sygn. I.371.8.398, Protokół zdawczo-odbiorczy referatu fortyfikacyjnego Kierownictwa Rejonu Inżynierii i Saperów, Toruń, 30 XI 1925 r.

${ }^{29}$ APT, sygn. 183/27, Pismo [Zarządu Fortyfikacyjnego DOW „Toruń”] do Dowództwa Miasta w Toruniu, nr 308 z dn. [13?] III 1920 r. 
były to m.in.: dom wałmistrza $\mathrm{z}$ ustępem zewnętrznym (oba w konstrukcji ryglowej), murowany magazyn, drewniana szopa ${ }^{30}$ i dwie hale ćwiczeń wzniesione z muru pruskiego ${ }^{31}$.

Budynki te istniały po zewnętrznej stronie drogi rokadowej twierdzy, na odcinku tuż przed jej ostrym skrętem w kierunku południowym. Jeden z obiektów (prawdopodobnie mieszkanie wałmistrza) znajdował się po lewej stronie drogi dojazdowej do fortu, na bardzo bliskim jego zapolu $^{32}$.

Po zachodniej stronie drogi rokadowej twierdzy, na południe od Fortu VII, znajdowała się szopa przeznaczona do składowania materiałów budowlanych, o wymiarach 20,0 × 6,0 m, w konstrukcji podobnej zapewne do pozostałych tego rodzaju obiektów ${ }^{33}$.

Następnym znaczącym dziełem obronnym w toruńskim pierścieniu fortecznym był Fort VIII „Warownia Kazimierza Wielkiego”. Po lewej stronie drogi dojazdowej (dzisiejszej ulicy Bielańskiej) ${ }^{34}$, w pobliżu fortu, znajdowała się niewielka grupa budynków. Dom wałmistrza o wymiarach $16,0 \times 10,0 \mathrm{~m}$ i wysokości 4,0 m był jednopiętrowy, wzniesiony $\mathrm{z}$ muru pruskiego $\mathrm{z}$ dachem dwuspadowym krytym papą. Na parterze było sześć ogrzewanych pokoi oraz kuchnia. Na poddaszu mieścił się strych. Obiekt miał podpiwniczenie oparte na drewnianym stropie. Obok domu stał drewniany ustęp $(3,0 \times 1,5 \mathrm{~m}) \mathrm{z}$ prostym dachem.

\footnotetext{
${ }^{30} \mathrm{~W}$ marcu $1920 \mathrm{r}$. były w niej składowane pewne materiały inżynieryjne, a jesienią tego roku znajdowały się tam paliki drewniane pochodzące ze zdemontowanych zasieków. APT, sygn. 183/27, Pismo [Zarządu Fortyfikacyjnego DOW „Toruń”] do Dowództwa Miasta w Toruniu, nr 308 z dn. [13?] III 1920 r.; Raport wałmistrza Watowskiego z dn. 3 XI $1920 \mathrm{r}$.

${ }^{31}$ CAW, sygn. I.371.8.398, Protokół zdawczo-odbiorczy referatu fortyfikacyjnego Kierownictwa Rejonu Inżynierii i Saperów, Toruń, 30 XI 1925 r.

${ }^{32}$ CAW, sygn. I.371.8.494, Warownia Kościuszki. Plan gruntów, 5 VI 1926 r.

${ }^{33}$ APT, sygn. 183/18, zał. I/1, Rozprawa oddawcza fortyfikacji w Toruniu; zał. I/3, Opis dzieł fortecznych, gruntów i budynków oddanych rządowi polskiemu przez fortyfikację; CAW, sygn. I.371.8.453, Wykaz budowli nieobronnych twierdzy Toruń; AMZP, Thorn, 1909, nr 2977, http://amzpbig.com/maps/2977_Thorn_1909.jpg, [dostęp z dn. 28.04.2016 r.].

${ }^{34}$ Fort miał dwie drogi dojazdowe od strony rokady twierdzy. Por. CAW, sygn. I.371.8.494, Warownia Kazimierza Wielkiego. Plan gruntów, 19 VI 1926 r.
} 
Standardowym budynkiem przyfortecznym była stajnia, którą zbudowano również przy Forcie VIII. Był to niewielki budynek dwukondygnacyjny $(5,0$ x 5,5 m) wzniesiony z muru pruskiego. Jednospadowy dach pokryty był papą ${ }^{35}$.

W okolicach Fortu IX „Warowni Bolesława Chrobrego”, w pobliżu skrzyżowania drogi rokadowej z szosą w kierunku Fordonu (przez Pędzewo), mieściła się kolejna, drewniana szopa na materiały budowlane, o wymiarach $8,0 \times 6,0 \mathrm{~m}^{36}$.

W przypadku budynków nieobronnych bezpośrednio związanych z Fortem IX istnieje podobna niepewność, jak w przypadku obiektów przy Forcie VII, gdyż pominięto je zupełnie w części dokumentacji pisemnej. Ich położenie pokazuje plan gruntów. Pewne jest, że obiekty zaznaczone na polskich mapach z połowy lat dwudziestych powstały przed powrotem miasta i twierdzy do Polski - nie pochodzą więc $z$ ewentualnej rozbudowy w okresie międzywojennym i istniały w roku 1920, kluczowym dla podjętego tematu. Cztery z nich były zlokalizowane po zachodniej stronie drogi rokadowej w bezpośrednim sąsiedztwie fortu, a jeden po stronie przeciwnej ${ }^{37}$ (ryc. 3). Ich położenie dobrze ukazują również mapy niemieckie sprzed I wojny światowej ${ }^{38}$.

Według cytowanego już „Protokołu zdawczo-odbiorczego referatu fortyfikacyjnego Kierownictwa Rejonu Inżynierii i Saperów” w Toruniu, przy Forcie IX znajdowały się: dom mieszkalny zbudowany z muru pruskiego, dwie szopy w konstrukcji ryglowej, murowany areszt i wartownia oraz hala ćwiczeń (mur pruski) ${ }^{39}$.

\footnotetext{
${ }^{35}$ APT, sygn. 183/18, zał. I/1, Rozprawa oddawcza fortyfikacji w Toruniu; zał. I/3, Opis dzieł fortecznych, gruntów i budynków oddanych rządowi polskiemu przez fortyfikację; CAW, sygn. I.371.8.453, Wykaz budowli nieobronnych twierdzy Toruń.

${ }^{36}$ Ibid.

${ }^{37}$ CAW, sygn. I.371.8.486, Warownia Bolesława Chrobrego. Plan gruntów, 6 VI $1926 \mathrm{r}$.

${ }^{38}$ AMZP, Thorn, 1909, nr 2977, http://amzpbig.com/maps/2977_Thorn_1909.jpg, [dostęp z dn. 28.04.2016 r.].

${ }^{39}$ CAW, sygn. I.371.8.398, Protokół zdawczo-odbiorczy referatu fortyfikacyjnego Kierownictwa Rejonu Inżynierii i Saperów, Toruń, 30 XI 1925 r.
} 


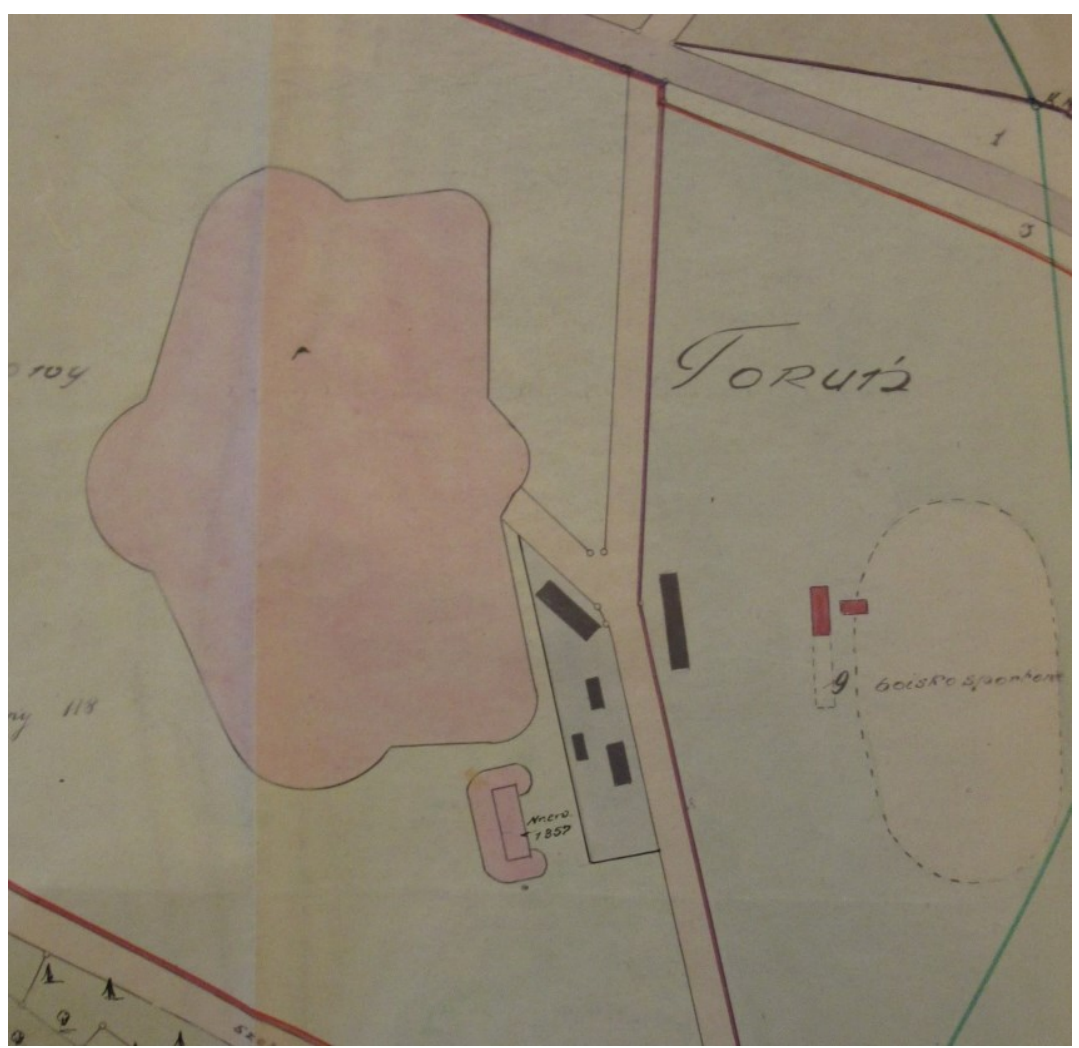

Ryc. 3. Obiekty zaplecza Fortu IX Twierdzy Toruń, stan z początku 1926 r. CAW, sygn. I.371.8.486, Warownia Bolesława Chrobrego.

Plan gruntów, 6 VI 1926 r. (fragment)

Obiekty nieobronne w lewobrzeżnej części zewnętrznego pierścienia fortecznego

Na zachodnim krańcu Twierdzy Toruń, po lewej stronie Wisły, tuż przy rzece zlokalizowany był Fort X „Bateria Nadbrzeżna”. W jego rejonie nie było klasycznych budynków zaplecza (dom wałmistrza, stajnia itp.), gdyż w okresie zaboru Niemcy nie klasyfikowali tego obiektu 
jako fortu, bo też w rzeczywistości nim nie był ${ }^{40}$. Kartografie z $1926 \mathrm{r}$. pokazują jednak istnienie dwóch podłużnych budynków (składów?) na bliskim zapolu fortyfikacji, które nie pochodzą $\mathrm{z}$ ewentualnej rozbudowy z okresu międzywojennego ${ }^{41}$.

Obok fortów VII i IX trzecim dziełem obronnym w pierścieniu fortecznym, przy którym znajdowały się w 1920 r. obiekty nieobronne, choć nie ujęte w większości oficjalnych spisów ${ }^{42}$, był Fort XI „Warownia Stefana Batorego". Zgodnie z planem gruntów po prawej stronie drogi (sięgacza) bezpośrednio prowadzącej do obiektu istniało pięć budynków ${ }^{43}$. Dom mieszkalny wałmistrza zbudowany był z muru pruskiego. Obok ulokowano szopę z przybudówką (ustępem), wzniesione w konstrukcji ryglowej. Przy forcie znajdowały się również dwie hale do ćwiczeń (z muru pruskiego i ryglówki), a także łaźnia z blachy falistej $^{44}$.

Grupa siedmiu budowli zaplecza towarzyszyła Fortowi XII „Warowni Władysława Jagiełly". Jednopiętrowy, murowany dom wałmistrza miał wymiary 13,5 x 10,5 m. Jego dwuspadowy dach był pokryty łupkiem. W przyziemiu znajdowały się cztery ogrzewane pokoje, kuchnia oraz spiżarnia. Piętro było podzielone pomiędzy pokój dla służby, dwie komory i strych. Piwnice w obiekcie składały się z czterech pomieszczeń. Koło domu znajdował się ustęp zbudowany z muru pruskiego, z jednospadowym dachem pokrytym papą. W tej samej konstrukcji wykonano stajnię (5,5 x 4,0 m).

Niedaleko Fortu XII stał też dom mieszkalny dla robotnika. Był to jednopiętrowy budynek z muru pruskiego, o wymiarach 10,0 x 8,0 m. Wewnątrz mieściły się trzy pokoje i kuchnia.

\footnotetext{
${ }^{40}$ Por. ibid.

${ }^{41}$ CAW, sygn. I.371.8.483, Bateria Nadbrzeżna. Plan gruntów, 22 VI 1926 r.

${ }^{42}$ Por. APT, sygn. 183/18, zał. I/1, Rozprawa oddawcza fortyfikacji w Toruniu; zał. I/3, Opis dzieł fortecznych, gruntów i budynków oddanych rządowi polskiemu przez fortyfikację; sygn. 183/19, [Regulacja wartości majątku twierdzy...], Operat szacunkowy gruntów; CAW, sygn. I.371.8.453, Wykaz budowli nieobronnych twierdzy Toruń.

${ }^{43}$ CAW, sygn. I.371.8.484, Warownia Stefana Batorego. Plan gruntów, 17 VI 1926 r.

${ }^{44}$ CAW, sygn. I.371.8.398, Protokół zdawczo-odbiorczy referatu fortyfikacyjnego Kierownictwa Rejonu Inżynierii i Saperów, Toruń, 30 XI 1925 r.
} 
Pozostałe obiekty zaplecza to: szopa na drewno $(6,0 \times 4,0 \mathrm{~m})$, szopa na cement $(15,0 \times 8,0$ - jedno pomieszczenie) i szopa wraz ze stajnią (15,0 x 8,0 - pięć pomieszczeń). Wszystkie zostały wykonane w konstrukcji ryglowej z szalunkiem z desek. Dach pokrywała papa. Budynki wybudowano przy drodze dojazdowej do fortu ${ }^{45}$.

Dość silnie rozwinięte było zaplecze Fortu XIII „Warowni Karola Kniaziewicza" (ryc. 4). Najbliżej fortu stał dom wałmistrza, który nie jest wzmiankowany w dokumentacji pisemnej, ale widoczny na planach $^{46}$. Po obu stronach drogi dojazdowej znajdowały się pozostałe budynki. Na planie kwadratu o boku 9,0 m wzniesiono drewniany dom mieszkalny dla robotnika (wysokość 4,0-5,5 m). Dach pokrywała papa. W przyziemiu mieściły się dwa ogrzewane pokoje oraz kuchnia. Wolno stojący ustęp miał wymiary 4,0 x 3,0 $\mathrm{m}$ i zbudowany był w tej samej konstrukcji.

Przy Forcie XIII istniały dwie szopy, pierwotnie przeznaczone do składowania materiałów budowlanych. Pierwsza z nich, mniejsza $(14,0$ x 9,0 m), znajdowała się na terenie fortecznym, tak jak prawie wszystkie obiekty omawiane w tym artykule. Odmiennie - na obszarze placu ćwiczeń dla artylerii - stała druga szopa, znacznie większa, gdyż licząca aż 25,0 m długości i 9,0 m szerokości. Oba obiekty były wykonane w konstrukcji ryglowej, szalowanej dodatkowo deskami, a dach pokrywała papa ${ }^{47}$.

Grupa budynków zaplecza mieściła się także na toruńskich Stawkach, przy szosie prowadzącej do Warszawy. Stanowiła zaplecze Fortu XIV „Warowni Józefa Dwernickiego”, mającego pełną fosę wodną. Głównym obiektem był murowany dom wałmistrza o zewnętrznych wymiarach 8,5 x 7,6 m, którego pokrycie dachowe (dwuspadowe) wy-

${ }^{45}$ APT, sygn. 183/18, zał. I/1, Rozprawa oddawcza fortyfikacji w Toruniu; zał. I/3, Opis dzieł fortecznych, gruntów i budynków oddanych rządowi polskiemu przez fortyfikację; CAW, sygn. I.371.8.453, Wykaz budowli nieobronnych twierdzy Torun.

${ }^{46}$ CAW, sygn. I.371.8.493, Warownia Kniaziewicza. Plan rejonu zakazu budowy, 4 VII $1926 \mathrm{r}$.

${ }^{47}$ APT, sygn. 183/18, zał. I/1, Rozprawa oddawcza fortyfikacji w Toruniu; zał. I/3, Opis dzieł fortecznych, gruntów i budynków oddanych rządowi polskiemu przez fortyfikację; CAW, sygn. I.371.8.453, Wykaz budowli nieobronnych twierdzy Toruń; sygn. I.371.8.493, Warownia Kniaziewicza. Plan rejonu zakazu budowy, 4 VII 1926 r. 


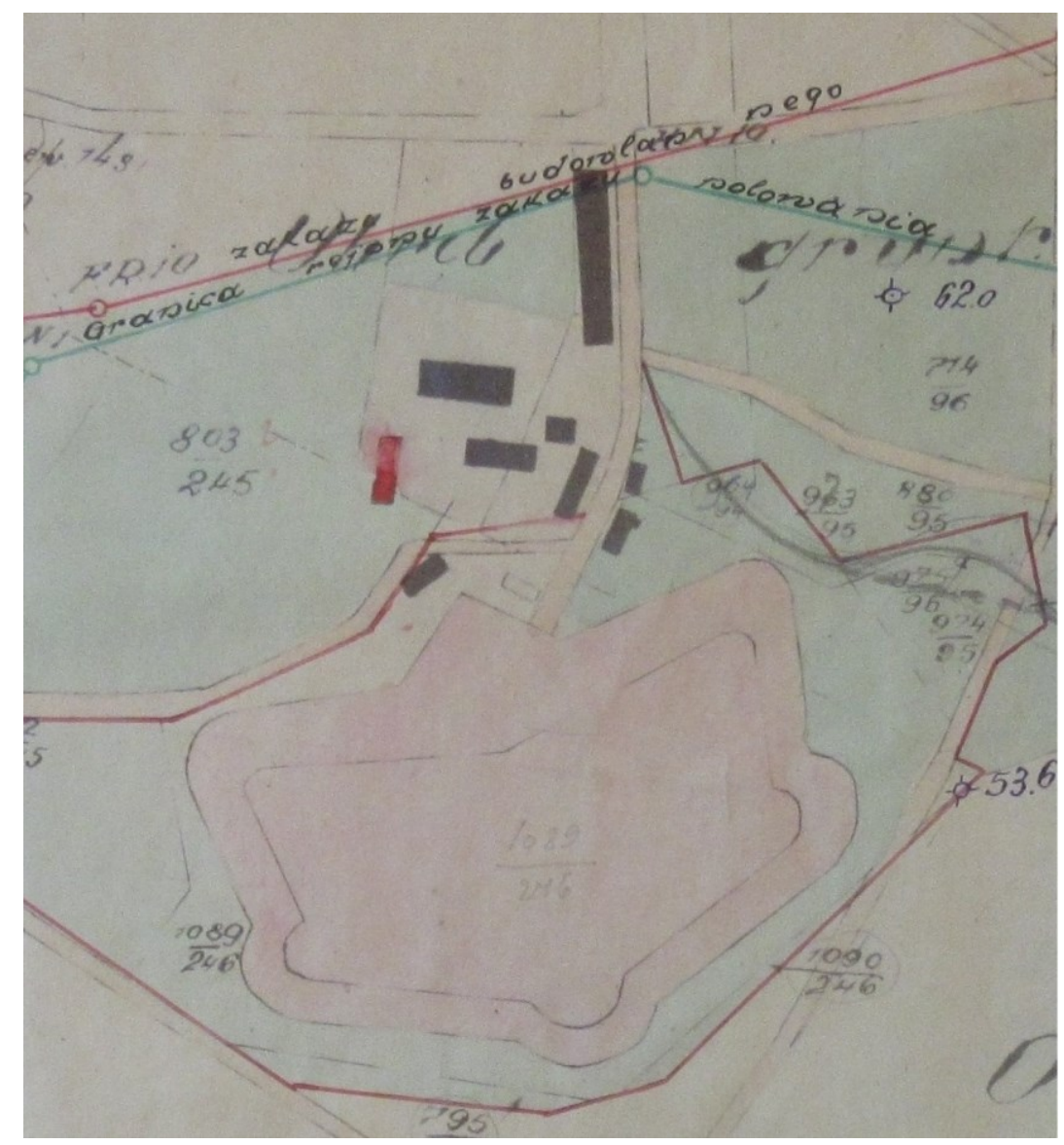

Ryc. 4. Budynki nieobronne na zapolu Fortu XIII, stan z początku 1926 r.

CAW, sygn. I.371.8.493, Warownia Kniaziewicza. Plan rejonu zakazu budowy, 4 VII 1926 r. (fragment)

konano $\mathrm{z}$ dachówki. Nad piwnicą z drewnianym stropem znajdowała się kondygnacja mieszkalna $z$ dwoma ogrzewanymi pokojami i kuchnią. Na poddaszu mieścił się jeden pokój bez pieca. Do budynku przylegała podłużna przybudówka $\mathrm{z}$ ustępem $(3,2$ x 1,4 m), wzniesiona $\mathrm{z}$ muru pruskiego. Jednospadowy dach kryty był papą. 
Standardowym uzupełnieniem gospodarstwa wałmistrza była stajnia, w tym wypadku o wymiarach 6,9 x 4,2 m i wysokości 2,7-3,15 m, zbudowana $\mathrm{z}$ muru pruskiego, $\mathrm{z}$ dachem pokrytym papą. Wewnątrz znajdowały się dwa pomieszczenia stajenne oraz izba pralni ${ }^{48}$.

W $1920 \mathrm{r}$. istniał fragment ogrodzenia posesji (prawdopodobnie wałmistrza) o długości $120 \mathrm{~m}$. Płot wykonano z drewnianych słupów o wysokości $1,5 \mathrm{~m} \mathrm{i} \mathrm{łat}{ }^{49}$ mocowanych do nich prostopadle za pomocą gwoź$\mathrm{dzi}^{50}$.

Przy drodze do Czerniewic, w pobliżu Fortu XIV, położony był dom mieszkalny robotnika fortecznego. Był to jednopiętrowy, murowany budynek. Pokrycie dwuspadowego dachu stanowiła dachówka. Obiekt miał wymiary 10,3 × $6,5 \mathrm{~m}$. W przyziemiu mieściły się dwa ogrzewane pokoje i dwa pomieszczenia kuchenne. Była tu też piwnica (dwie komory ze stropem z drewnianych belek). W pobliżu znajdowała się murowana stajnia kryta papą. Wewnątrz wydzielono jedno pomieszczenie stajenne i ustęp. Całość miała wymiary $5,9 \times 3,5 \mathrm{~m}^{51}$.

Ostatnim dużym dziełem fortyfikacyjnym w lewobrzeżnej części pierścienia zewnętrznego twierdzy toruńskiej był wysunięty na wschód Fort XV „Warownia Henryka Dąbrowskiego”. Przy drodze prowadzącej $\mathrm{w}$ kierunku tego fortu istniała spora grupa obiektów nieobronnych $^{52}$ (ryc. 5). Służbowy dom mieszkalny wałmistrza, o wymiarach 10,0 x 9,0 m i wysokości 4,0-4,5 m, wzniesiono w konstrukcji ryglowej. Ściany oszalowano dodatkowo deskami. Dwuspadowy dach pokrywała papa. Na parterze mieściły się dwa ogrzewane pokoje. Prawdopodobnie był to jedyny dom wałmistrza w pierścieniu zewnętrznym twier-

${ }^{48}$ APT, sygn. 183/18, zał. I/1, Rozprawa oddawcza fortyfikacji w Toruniu; zał. I/3, Opis dzieł fortecznych, gruntów i budynków oddanych rządowi polskiemu przez fortyfikację; CAW, sygn. I.371.8.453, Wykaz budowli nieobronnych twierdzy Toruń.

${ }^{49}$ Łata - drewniana listwa o przekroju prostokątnym lub kwadratowym, używana w konstrukcjach drewnianych. Często występuje m.in. w więźbie dachowej, gdzie służy do ułożenia pokrycia dachowego.

${ }_{50}$ APT, sygn. 183/18, zał. I/1, Rozprawa oddawcza fortyfikacji w Toruniu; zał. I/3, Opis dzieł fortecznych, gruntów i budynków oddanych rządowi polskiemu przez fortyfikacje; CAW, sygn. I.371.8.453, Wykaz budowli nieobronnych twierdzy Toruń.

${ }^{51}$ Ibid.

${ }^{52}$ CAW, sygn. I.371.8.414, Sytuacja budynków przy forcie Dąbrowskiego, L. ew. 249/B, b.d. 


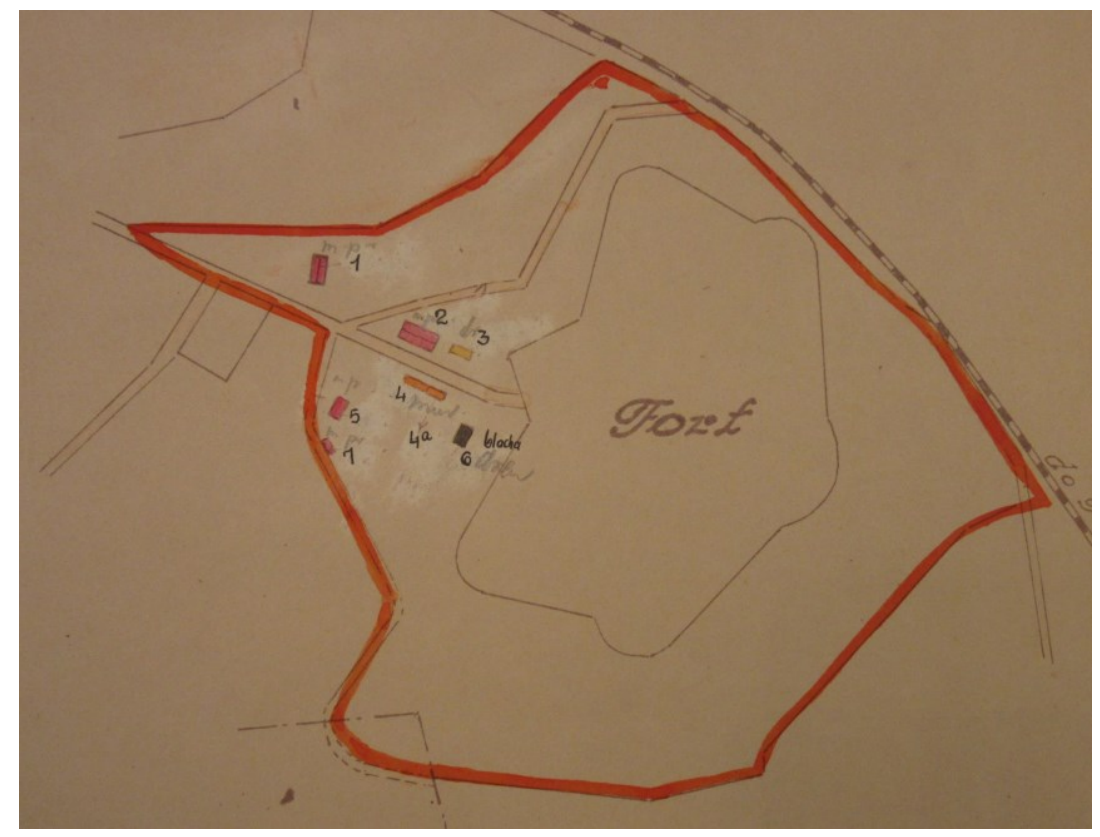

Ryc. 5. Obiekty przyforteczne na zapolu Fortu XV. CAW, sygn. I.371.8.414, Sytuacja budynków przy forcie Dąbrowskiego, L. ew. 249/B, b.d. (fragment)

dzy, który nie miał podziemnej kondygnacji piwnicznej. Do budynku przylegała niewielka przybudówka $(3,5$ x 2,0 m) o identycznej konstrukcji budowlanej, która nie pełniła jednak funkcji sanitariatu - ustęp powstał osobno i był nieco większy: 4,0 x 3,0 m.

$\mathrm{Na}$ początku lat dwudziestych istniała jeszcze część parkanu grodzącego parcelę forteczną, na której wzniesione były wyżej omówione obiekty. Płot miał $40 \mathrm{~m}$ długości i $1,5 \mathrm{~m}$ wysokości. Był wykonany $\mathrm{z}$ drewnianych słupów i łat ${ }^{53}$.

Kolejne budynki, które znajdowały się na zapolu Fortu XV, przy drodze do niego, to: dom robotnika oraz stajnia i pralnia. Obiekt mieszkalny wykonany był z muru pruskiego, jako jednopiętrowy z dwuspa-

${ }^{53}$ Ibid. 
dowym dachem, który pokrywała papa. Jego długość wynosiła 10,0 m, a szerokość 7,5 m. Składał się z piwnicy, dwóch ogrzewanych piecami pokoi i kuchni oraz strychu. Stajnia i pralnia miały identyczną konstrukcję budowlaną. Oba te obiekty były jednak mniejsze - stajnia miała wymiary $6,5 \times 5,0 \mathrm{~m}$, natomiast pralnia $-6,0 \times 4,0 \mathrm{~m}$.

$\mathrm{Na}$ posesji zachował się fragment ogrodzenia wykonanego ze słupów i sztachet drewnianych o wysokości $1,5 \mathrm{~m}$. Łączna długość wynosiła $60,0 \mathrm{~m}^{54}$.

Wśród pozostałych budynków przyfortecznych w tym rejonie można wymienić: dwie hale ćwiczeń z muru pruskiego i łaźnię wzniesioną $\mathrm{z}$ blachy falistej ${ }^{55}$.

\section{Stan przekazanych polskiej administracji wojskowej obiektów przyfortecznych pierścienia zewnętrznego, ich remonty i zagospodarowanie}

Państwo niemieckie, po zakończeniu Wielkiej Wojny, na mocy ustaleń międzynarodowych zobowiązane było przekazać na rzecz niepodległej Rzeczypospolitej miasta i twierdze, w tym Toruń, w stanie niepogorszonym w stosunku do dnia 1 sierpnia 1914 r. ${ }^{56}$ Dotyczyło to istniejących budynków koszar, różnych magazynów i składnic (łącznie ze znajdującymi się tam zapasami), obiektów nieobronnych bezpośredniego zaplecza umocnień, a przede wszystkim samych dzieł fortyfikacyjnych.

Niemcy, świadomie ignorując przyjęte na konferencji pokojowej w Wersalu (28 VI 1919 r.) powyższe warunki, rozpoczęli na ogromną skalę demontaż wyposażenia i sprzętów wojennych (w tym broni), które natychmiast wywozili w głąb kraju. Wszystkie składy i magazyny opustoszały. Każda rzecz, która choćby potencjalnie mogła mieć

\footnotetext{
${ }^{54}$ Ibid.

${ }^{55}$ CAW, sygn. I.371.8.398, Protokół zdawczo-odbiorczy referatu fortyfikacyjnego Kierownictwa Rejonu Inżynierii i Saperów, Toruń, 30 XI 1925 r.

${ }^{56}$ A. Aleksandrowicz, Odbiór od Niemców twierdz pomorskich od 9.1 .1920 do 15.11.1920, [w:] Księga pamiatkowa dziesięciolecia Pomorza, red. K. Esden-Tempski, Toruń 1930, s. 112.
} 
jakąś wartość - a zwłaszcza to, czego nie zdążono wywieźć do Niemiec do momentu, w którym zbliżał się czas przekazania miasta Polsce - została sprzedana po zaniżonej cenie miejscowej ludności. Choć żadne $\mathrm{z}$ ważniejszych dzieł obronnych nie zostały rozebrane, ich wnętrza zostały ogołocone $\mathrm{z}$ większości uzbrojenia, urządzeń i sprzętów. Poza częściami pancernymi demontowano nawet niektóre drewniane drzwi i podłogi, mechanizmy instalacji oświetlenia elektrycznego czy wentylacji, inne elementy celowo zniszczono ${ }^{57}$.

Ten sam los spotkał obiekty nieobronne towarzyszące fortyfikacjom. Nie miały one specjalistycznych instalacji, jednak pozbawiono je w dużej części nawet sprzętów codziennego użytku, takich jak meble (stoły, krzesła, łóżka) czy oświetlenie (żarówki lub lampy naftowe), a niektóre $\mathrm{z}$ nich zniszczono. W poniższym zestawieniu sporządzonym na podstawie załącznika $\mathrm{nr} 2$ do protokołu zdawczo-odbiorczego Twierdzy Toruń, w którym ujęto sprzęty znajdujące się w fortyfikacjach i obiektach nieobronnych mające zostać przekazane Polsce na początku 1920 r., wykazano elementy wyposażenia pozostawione w budynkach zaplecza przy fortach:

- Fort VIII: w mieszkaniu wałmistrza i w kancelarii wartowni przy forcie: stół, dwie szafy, krzesło, umywalka, skrzynia na dokumenty;

- Fort XIV: w mieszkaniu wałmistrza: stół, regał, szafa, szkielet łóżka ${ }^{58}$.

Opierając się na tej podstawie, jak i pozostałych przesłankach, można wysnuć ostrożny wniosek, że w poszczególnych budynkach - w momencie ich przekazania - znajdowały się jedynie pojedyncze sprzęty. Być może niektóre $\mathrm{z}$ budowli zostały całkowicie pozbawione wyposażenia wewnętrznego, na co wskazywałoby jednoznacznie powyższe, bardzo krótkie zestawienie. O ile w przypadku stajni, stodół i szop nie stanowiło to rażącej przeszkody, o tyle w odniesieniu do dawnych domów wałmistrzów i robotników było kolejną trudnością, z którą musiały zmierzyć się polskie władze cywilne i wojskowe w przywracaniu

\footnotetext{
${ }^{57}$ APT, sygn. 183/19, Meldunek szefa Zarządu Fortyfikacyjnego w Toruniu do szefa Inżynierii i Saperów Okręgu Korpusu nr VIII w Toruniu, L.dz. 5476 z dn. 11 IX $1922 \mathrm{r}$.

${ }^{58}$ APT, sygn. 183/18, Rozprawa w sprawie sprzętów oddanych rządowi polskiemu przez fortyfikację, Toruń, 13 I 1920 r., zał. 2.
} 
pełnej przydatności tych obiektów oraz ich zagospodarowaniu i użytkowaniu dla własnych, nowych potrzeb.

Nieznany pozostaje dokładny stan techniczny budynków nieobronnych na początku lat dwudziestych XX w. W 1920 r., w okresie letnim, Wojskowy Rejon Budowlano-Kwaterunkowy w Toruniu przeprowadzał oględziny obiektów przy fortach, które miały być zajęte przez wałmistrzów i dozorców wałowych na cele kwaterunkowe ${ }^{59}$.

$\mathrm{Z}$ dokumentów wiadomo, że niektóre elementy konstrukcyjne budowli wymagały pilnych remontów. Najczęściej w złym stanie były pokrycia dachowe, które przepuszczały wodę w czasie deszczu, powodując dalsze uszkodzenia, wpływające na pogorszenie stanu technicznego całego budynku. Tak było m.in. w domach przeznaczonych dla stróżów przy fortach XII i XIII, gdzie w końcu sierpnia 1920 r. miał się rozpocząć remont dachów ${ }^{60}$. W nie najlepszym stanie były również inne obiekty. Szybkiego remontu wymagały szopa przy Forcie I i dom wałmistrza (jako mieszkanie dozorcy wałowego) na zapolu Fortu II $^{61}$.

Nieco szczegółowych danych zachowało się dla drugiej połowy roku 1921. W sierpniu naprawiono dachy na trzech budynkach mieszkalnych i dwóch stajniach. Koszt prac dekarskich wyniósł łącznie 235 486,6 marek polskich (dalej mk) ${ }^{62}$. We wrześniu za kwotę 49496 mk wyreperowano dach na jednej z przyfortecznych stajni ${ }^{63}$. W kolejnym miesiącu remontowano pokrycia dachowe na dwóch domach i pralniach oraz ustępie. Odpłatność za prace sięgnęła sumy 359 142,95 mk ${ }^{64}$. Nadzór nad tymi działaniami najczęściej mieli wałmistrze.

\footnotetext{
59 APT, sygn. 183/27, Pismo Wojskowego Rejonu Budowlano-Kwaterunkowego (dalej cyt. Wojsk. Rej. Bud.-Kwat.), L.dz. 6246/20 B z dn. 5 VIII 1920 r.

${ }^{60}$ APT, sygn. 183/27, Pismo Wojsk. Rej. Bud.-Kwat., L.dz. 5702/20 z dn. 20 VIII $1920 \mathrm{r}$.

${ }^{61}$ APT, sygn. 183/27, Pisma Zarządu Fortyfikacyjnego DOW „Toruń”, L.dz. 62/21 F z dn. 12 I 1921 r. i L.dz. 190/21 z dn. 31 I 1921 r. wzmiankowane w piśmie tegoż, Ldz. 264/21 F z dn. 15 II $1921 \mathrm{r}$.

${ }^{62}$ APT, sygn. 183/47, Sprawozdanie z przeprowadzonych w sierpniu 1921 r. robót konserwacyjnych i rozbiórki, zał. do L.dz. 223/21 F. Tj. z dn. 16 IX $1921 \mathrm{r}$.

${ }^{63}$ APT, sygn. 183/47, Sprawozdanie z przeprowadzonych we wrześniu 1921 r. robót konserwacyjnych i rozbiórki, zał. do L.dz. 254/21 F. Tj. z dn. 15 X 1921 r.

${ }^{64}$ APT, sygn. 183/47, Sprawozdanie z przeprowadzonych w październiku $1921 \mathrm{r}$. robót konserwacyjnych i rozbiórki, zał. do L.dz. 18/21 Tj. z dn. 17 XI 1921 r.
} 
Remonty obiektów przyfortecznych były zalecane przez Zarząd Fortyfikacyjny DOW „Toruń, jednak Departament V Inżynierii i Saperów Ministerstwa Spraw Wojskowych w Warszawie nie zawsze przychylnie odnosił się do ich finansowania z kredytów (budżetów) przyznanych na konserwację fortyfikacji. W październiku 1921 r. zabroniono pokrywać koszty remontów, m.in. w domach mieszkalnych przy fortach, z funduszy na naprawy umocnień. Wskazano jednocześnie na kredyty budowlane udzielane na pokrycie kosztów konserwacji i utrzymania budynków wojskowych, jako odpowiedniejsze do tych celów. Instytucją, która je otrzymywała, był Zarząd Budownictwa Wojskowego $^{65}$.

Konserwacje w omawianych obiektach kontynuowano w całym okresie międzywojennym. Wśród napraw, których dokonywano, można wymienić następujące:

- roboty dekarskie (na wszystkich rodzajach pokryć dachowych),

- uzupełnienia w konstrukcji budowlanej obiektów (w konstrukcjach ryglowych, w tym z muru pruskiego),

- tynkowanie ścian,

- malowanie ścian i sufitów,

- malowanie i lakierowanie drewnianych podłóg,

- naprawa rynien okapowych,

- remonty stolarki okiennej,

- wstawianie szyb w oknach,

- naprawa instalacji grzewczych (kominów i pieców - uszczelnienie palenisk gliną oraz wymiana spoin kafli),

- remonty pieców kuchennych (uszczelnienie palenisk gliną w piecach kaflowych oraz wymiana rusztów),

- naprawa zamków do drzwi ${ }^{66}$.

Jak już wcześniej wspomniano, przyforteczne obiekty nieobronne po przejęciu przez polskie wojsko zostały w części zagospodarowane. Większość domów ponownie pełniła swoje pierwotne funkcje, stając

\footnotetext{
${ }^{65}$ APT, sygn. 183/46, Pismo Ministerstwa Spraw Wojskowych, Dep. V Inż. i Sap., nr 4242/21/V z dn. 8 X $1921 \mathrm{r}$.

${ }^{66} \mathrm{CAW}$, sygn. I.371.8.451, Wykaz robót konserwacyjnych w obiektach fortecznych z Dz. Budż. Int. dz. 1 - rozdz. 1 - 5 .
} 
się mieszkaniami najczęściej samych wałmistrzów i dozorców wałowych $^{67}$. W szopach i magazynach urządzano doraźne składy dla różnych materiałów, głównie inżynieryjnych ${ }^{68}$, w tym początkowo pochodzących z rozbiórek fortyfikacji polowych ${ }^{69}$. Najczęściej przejściowo użytkowano stajnie, wykorzystując je również jako zapasowe, dla tych znajdujących się w fortach. Niektóre obiekty odgrywały rolę wartowni, zwłaszcza przy fortyfikacjach, które otrzymały stały dozór. Funkcje części budowli przyfortecznych zmieniały się, dlatego na ogół trudne jest precyzyjne wskazanie poszczególnych $\mathrm{z}$ nich wraz $\mathrm{z}$ danym przeznaczeniem w konkretnym zakresie chronologicznym.

Rzeczywistość, z którą zetknęła się polska wojskowa komisja odbiorcza $^{70}$ w Toruniu na początku 1920 r., znacząco różniła się od stanu zachowania obiektów pierwotnie uzgodnionego w wyniku pertraktacji pokojowych. W porównaniu z przejęciem samego miasta przekazanie i odbiór twierdzy trwały ponad cztery tygodnie. Prace członków komisji utrudniał brak dokumentacji wytworzonej przez niemiecki urząd fortyfikacyjny (Fortification Thorn), która została świadomie wywieziona jeszcze przed styczniem 1920 r. do Berlina, gdzie weszła w skład zbiorów Archiwum Sztabu Generalnego. Opracowanie protokołów zdawczo-odbiorczych twierdzy toruńskiej ukończono wraz z przedstawicielami strony niemieckiej dopiero na przełomie stycznia i lutego.

Pole badawcze w przypadku obiektów nieobronnych zewnętrznego pierścienia fortecznego Twierdzy Toruń, jak również w odniesieniu do wielu innych aspektów historii tego założenia obronnego, jest wciąż

\footnotetext{
${ }^{67}$ Zob. choćby: APT, sygn. 183/27, Pismo Zarządu Fortyfikacyjnego DOW „Toruń”, Ldz. 264/21 F z dn. 15 II 1921 r.; sygn. 183/46, Tajne pismo Zarządu Fortyfikacyjnego DOW „Toruń, L.dz. 1177/21 F z dn. 25 VII 1921 r.; Pismo Zarządu Fortecznego Toruń, L.dz. 729/28 z dn. [?] X 1928 r.

${ }^{68}$ APT, sygn. 183/27, Pismo [Zarządu Fortyfikacyjnego DOW „Torun”] do Dowództwa Miasta w Toruniu, nr 308 z dn. [13?] III $1920 \mathrm{r}$.

${ }^{69}$ APT, sygn. 183/27, Raport wałmistrza Watowskiego z dn. 3 XI 1920 r.

${ }^{70} \mathrm{O}$ problematyce formowania wojskowych komisji odbiorczych, w tym budowlanych, intendenckich i sanitarnych, szerzej zob.: Księga pamiatkowa, s. 105-106; A. Aleksandrowicz, op. cit., s. 111-112.
} 
otwarte. Należy podjąć próby określenia formy i skali użytkowania tych budynków w kolejnych latach dwudziestolecia międzywojennego, choć ze względu na braki w zachowanej dokumentacji może być to trudne. Warto zwrócić też uwagę na dokonanie ustaleń dotyczących stanu technicznego budowli przyfortecznych w następnych okresach dziejów, a przede wszystkim podczas II wojny światowej i w czasach Polski Ludowej. 